\title{
Refined Radiocarbon Chronologies for Northern Iroquoian Site Sequences: Implications for Coalescence, Conflict, and the Reception of European Goods - CORRIGENDUM
}

\author{
Jennifer Birch, Sturt W. Manning, Samantha Sanft, and Megan Anne Conger
}

DOI:10.1017/aaq.2020.73, Published online by Cambridge University Press, September 22, 2020

The authors of this article (Birch et al. 2020) wish to correct the stated European copper association for an artifact from the Onondaga Barnes site (cat no. NYSM A2009.35K.99.28). The pXRF results could well be consistent with native copper. The $\mathrm{Cu}$ percent is slightly lower than for another copper artifact from the site (NYSM A2009.35K.99.42), but the other trace elements do not clearly suggest a European attribution. We thank James Bradley for bringing this matter to our attention.

\section{Reference Cited}

Birch, Jennifer, Sturt W. Manning, Samantha Sanft, and Megan Anne Conger

2020 Refined Radiocarbon Chronologies for Northern Iroquoian Site Sequences: Implications for Coalescence, Conflict, and the Reception of European Goods. American Antiquity, in press. DOI:10.1017/aaq.2020.73. 